\section{Scientific journal}

\section{PHYSICAL AND MATHEMATICAL EDUCATION}

Has been issued since 2013.

Науковий журнал

ФІЗИКО-МАТЕМАТИЧНА ОСВІТА

Видається з 2013.
ISSN 2413-158X (online)

ISSN 2413-1571 (print)

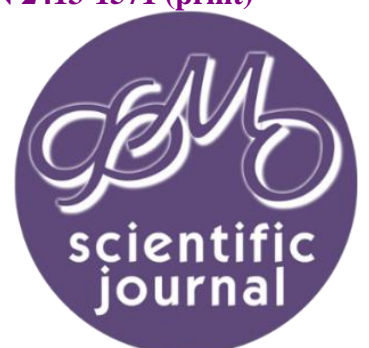

Дєордіца Т.Ю., Вороніна М.В., Литвинова Н.В. Специфіка оцінювального інструмента «Концептуальна рамка викладання» Ш. Даніелсон (з досвіду США). Фізико-математична освіта. 2021. Випуск 4(30). С. 46-53.

Dieorditsa T., Voronina M., Litvinova N. Specificity of the evaluating instrument of Danielson framework for teaching (the U.S. experience). Physical and Mathematical Education. 2021. Issue 4(30). P. 46-53.

DOI 10.31110/2413-1571-2021-030-4-007

удк 37.07:005.95/.96

Т.Ю. Дєордіца

Благодійний фонд «е-Terra», Україна

tdeor@i.ua

ORCID: https://orcid.org/0000-0002-3409-7168

М.В. Вороніна

Київський національний університет культури і мистеитв, Україна

m_voronina@i.ua

ORCID: https://orcid.org/0000-0003-3838-7194

Н.В. Литвинова

Глухівський національний педагогічний університет імені Олександра Довженка, Україна

litvinova_n@i.ua

ORCID: https://orcid.org/0000-0003-4606-5259

\title{
СПЕЦИФІКА ОЦІНЮВАЛЬНОГО ІНСТРУМЕНТА «КОНЦЕПТУАЛЬНА РАМКА ВИКЛАДАННЯ» Ш. ДАНІЕЛСОН
} (з досвіду США)

\section{АНОТАЦІЯ}

Формулювання проблеми. За нашими спостереженнями, наборам оцінювальних критеріїв професійної компетентності педагогічних працівників, що їх розробили фрахівці Державної служби якості освіти України у 2019-2020 рр., бракує такої важливої властивості, як “вимірюваність». Адже саме вимірювані критерії дозволяють виявляти рівні прояву професіоналізму. Для цього необхідні шкали критеріїв. Якщо ж їх немає, експертне оцінювання підмінюється контролем за дотриманням вимог. А це дискредитує ідею «оцінювання для професійного розвитку». Відтак вважаємо актуальним огляд провідних зарубіжних оцінювальних технологій ефективного викладання. Наша розвідка спрямовувалася таким дослідним питанням: якою є специфіка оцінювальних інструментів педагогічної праці, що застосовуються у США?

Матеріали і методи. Для відповіді на поставлене питання у статті з позицій системного підходу розглянуто досить популярний в освітній системі США критеріальний комплекс для оцінювання викладацької праці, відомий як "Fraтешоrk for Teaching. Evaluation Instrument» 三 «Концептуальна рамка викладання. Оцінювальний інструмент». Його автори дослідна група на чолі з Ш. Даніелсон.

Результати. Концептуальна рамка викладання Ш. Даніелсон репрезентує критеріальний комплекс, необхідний для здійснення експертного оцінювання ефективності процесуальної сторони вчительської праці. Його ядром є набір з 22 критеріїв. Вони характеризують ті професійні якості педагогів, котрі достовірно корелюють із досягненнями студентів/учнів. Для кожного критерію встановлені показники, що конкретизують його найважливіші прояви; визначено індикатори, необхідні для побудови шкали критерію; прописано оцінювальні судження, які утворюють шкалу критерію.

Висновки. За результатами нашої розвідки ми виявили чотири відмітні особливості розглянутої концептуальної рамки викладання, котрі відрізняють їі від набору сертифікаційних критеріїв, розроблених Державною службою якості освіти України: 1) рамка грунтується на ідеях педагогічного конструктивізму; 2) представлені у ній оцінювальні критерії є універсальними для різних викладацьких спеціалізацій; 3) набір цих критеріїв є повним, дієвим і вимірюваним; 4) рамка забезпечує дві функції оцінювання - оцінювання для професійного розвитку та оцінювання для контролю.

КЛЮчОВІ СЛОВА: вчительська праця, оцінювальний інструмент, експертне оцінювання, набір критеріїв, критеріальний комплекс, педагогічний конструктивізм, залучення до учіння. 


\section{ВСТУП}

Постановка проблеми. у 2019 р. в Україні як експериментальний проєкт розпочалося зовнішнє оцінювання вчительської праці - добровільна сертифікація вчителів. За нашими спостереженнями, наборам оцінювальних критеріїв професійної компетентності педагогічних працівників, що їх розробили фахівці Державної служби якості освіти України у 2019-2020рр., бракує такої важливої властивості, як «вимірюваність». Адже саме вимірювані критерії дозволяють виявляти рівні прояву професіоналізму. Вимірюваність критеріїв забезпечують розроблені для них шкали. Якщо ж їх немає, експертне оцінювання підмінюється контролем за дотриманням вимог. А це дискредитує ідею «оцінювання для професійного розвитку». Відтак вважаємо актуальним огляд провідних зарубіжних оцінювальних технологій ефективного викладання. Адже з'ясування їх специфіки може бути корисним для удосконалення вітчизняної методики розроблення критеріїв оцінки вчительської праці.

Аналіз актуальних досліджень. Ґрунтовну розвідку експертизи праці вчителя у провідних зарубіжних країнах здійснив В.Загвоздкін. Дослідник дійшов висновку, що суттєвою $є$ не тільки власне якість оцінювальних інструментів, а й якість управлінських механізмів і культура відносин, у межах яких ці інструменти використовують (В. Загвоздкін, 2018).

Особливо цінною для нашої розвідки була докторська дисертація Дж. Мосcа (J. Moss), присвячена вивченню сприйняття вчителями концептуальної рамки викладання Ш. Даніелсон. У цьому дослідженні ретельно окреслено загальну картину розвитку системи оцінювання вчительської праці у США та надано вичерпний огляд відповідних інформаційних джерел.

Аналіз американської оцінювальної практики щодо ефективного викладання на межі XX i XXI ст. здійснив Ст. Кентрелл (St. Cantrell). Дослідник вказує, що більшість чинних на той час у США оцінювальних практик не викликали довіри у зв'язку 3 тим, що недосконалі інструменти та їх погана реалізація давали величезні похибки вимірювання. На його думку, основна проблема полягала в тому, що між зацікавленими сторонами в галузі освіти не було згоди стосовно того, як визначати і вимірювати ефективне викладання. Спробу розв'язати цю проблему було здійснено у межах масштабного проєкту «The Measures of Effective Teaching» 三 «Заходи ефективного викладання» (2009-2011), виконаного за підтримки Фонду Білла та Мелінди Гейтс (St. Cantrell, 2012).

Україномовні дослідні публікації з питань оцінювання педагогічної праці у США належать І. Зварич, яка детально розглянула стандарти викладання для вчителів-початківців, запропоновані Міждержавним консорціумом з оцінювання та підтримки нового вчителя (Interstate New Teacher Assessment and Support Consortium - INTASC) (I. Зварич, 2014).

Цілком поділяючи думку І. Зварич про доцільність вивчення зарубіжного досвіду з метою вдосконалення вітчизняної освіти, ми обрали для розгляду оцінювальний інструмент викладацької практики, розроблений американськими дослідниками на чолі з Шарлоттою Даніелсон.

Мета статті полягає у виявленні специфіки критеріального комплексу, репрезентованого у документі «Framework for Teaching. Evaluation Instrument» 三 «Концептуальна рамка викладання. Оцінювальний інструмент» (Ch. Danielson, 2013).

\section{ТЕОРЕТИЧНІ ОСНОВИ ДОСЛІДЖЕННЯ}

Оцінювання роботи - це процедура, що використовується для визначення відносної цінності роботи в організації, що у свою чергу допомагає визначити рівень заробітної плати (П. Мучинські, 2003). Підставою для оцінювання роботи $€$ набір критеріїв. У науці критерієм прийнято називати сутнісну властивість (ознаку) явища, на основі якої здійснюється його оцінювання. (Т. Строкова, 2015). Відправною точкою для формування набору критеріїв оцінювання будь-якої роботи $€$ вияв належних змінних, адже розглядати роботу можна як з позицій задач професійної діяльності, так і з позицій працівників. Задачі та якості працівників виявляються за допомогою набору процедур методу «Аналіз роботи». Задачі - це базові елементи професійної діяльності, пов'язані із конкретними професійними цілями. Процедури, зорієнтовані на працівника, застосовуються для визначення знань, умінь, здібностей та інших характеристик, що уможливлюють успішне виконання професійних задач (П. Мучинські, 2003).

Частковим випадком оцінювання роботи $є$ оцінювання вчительської праці. Зважаючи на ії багатомірність, слід з'ясувати, які сторони вчительської праці можуть піддаватися оцінюванню? Відповідь на це питання випливає з аналізу психології праці вчителя, здійсненого А. Марковою з позицій діяльнісного підходу. Дослідниця встановила, що:

- зміст вчительської праці - сприяння психічному розвитку учня;

- головний «інструмент» вчителя - його психологічні взаємодії з учнями;

- складові процесу вчительської праці - педагогічна діяльність, педагогічне спілкування та професійна самореалізація особистості вчителя;

- результат вчительської праці - навченість і вихованість школярів (А. Маркова, 1993).

Отже, об'єктом оцінювання вчительської праці може бути і їі процес, і результат.

Оцінювання вчительської праці як частковий випадок оцінювання роботи - це конкретний приклад загальної задачі експертного оцінювання. Остання виникає на різних етапах процесу прийняття рішень, який зводиться до розв'язання двох послідовних задач вибору:

1) вибору множини допустимих оцінок (МДО) розглядуваної системи (альтернативи або критерію);

2) вибору з МДО оцінки, яка найбільш точно виражає властивості оцінюваної системи.

Операцію з визначення множини допустимих оцінок називають задачею оцінювання, розв'язання цієї задачіекспертизою, а зіставлення множини допустимих оцінок з критерієм - оцінюванням (І. Макаров та ін., 1982).

Кожен критерій має бути забезпечений показниками, тобто характеристиками, що конкретизують його найважливіші грані. Для кожного критерію наводиться або складається шкала, що містить множину впорядкованих оцінок. Побудові шкали передує формування емпіричних індикаторів, тобто спостережуваних ознак критерію або його показників. У теорії прийняття рішень до набору критеріїв висувають низку вимог. Ось їх стислий перелік: повнота, дієвість, розкладність, ненадмірність, мінімальність, вимірюваність. (М. Гафт, 1979). Набір критеріїв, їх показники, індикатори і шкали становлять критеріальний комплекс (Т. Строкова, 2015). 


\section{МЕТОДИ ДОСЛІДЖЕННЯ}

Схема вивчення концептуальної рамки викладання Ш.Даніелсон ґрунтувалася на основній характеристиці системного підходу - можливості розглядати будь-який об'єкт у трьох аспектах: як щось ціле (систему), як частину більш загальної системи (надсистеми) та як сукупність дрібніших частин (підсистем) .

\section{РЕЗУЛЬТАТИ ДОСЛІДЖЕННЯ}

Концептуальна рамка викладання Ш. Даніелсон репрезентує критеріальний комплекс, необхідний для здійснення експертного оцінювання ефективності процесуальної сторони вчительської праці. Експерт, користуючись шкалами критеріїв, має обрати з них ті оцінювальні судження, що містять якнайточніші оцінки спостережуваної ним поведінки вчителя у класі, а також якості створених учителем документів і артефактів.

Серед безлічі конкуруючих оцінювальних інструментів ми обрали саме рамку викладання Ш. Даніелсон тому, що:

1) вона була однією з п'яти моделей оцінювання вчительської праці, що ретельно вивчалися у межах проєкту «ТTе Measures of Effective Teaching» (Ch. Danielson, 2013);

2) іï найчастіше, порівняно з іншими аналогічними інструментами, застосовують у шкільних округах США (P. Moss, 2015);

3) ї̈ зміст узгоджено зі стандартами Міждержавного консорціуму INTASC (Ch. Danielson, 2013).

Встановити надсистему, частиною якої $€$ концептуальна рамка викладання Ш. Даніелсон, нам допомогла схема, на якій відображено структуру системи оцінки шкільної освіти, рекомендовану країнам - членам Організації економічного співробітництва та розвитку (ОЕСР) (рис. 1).

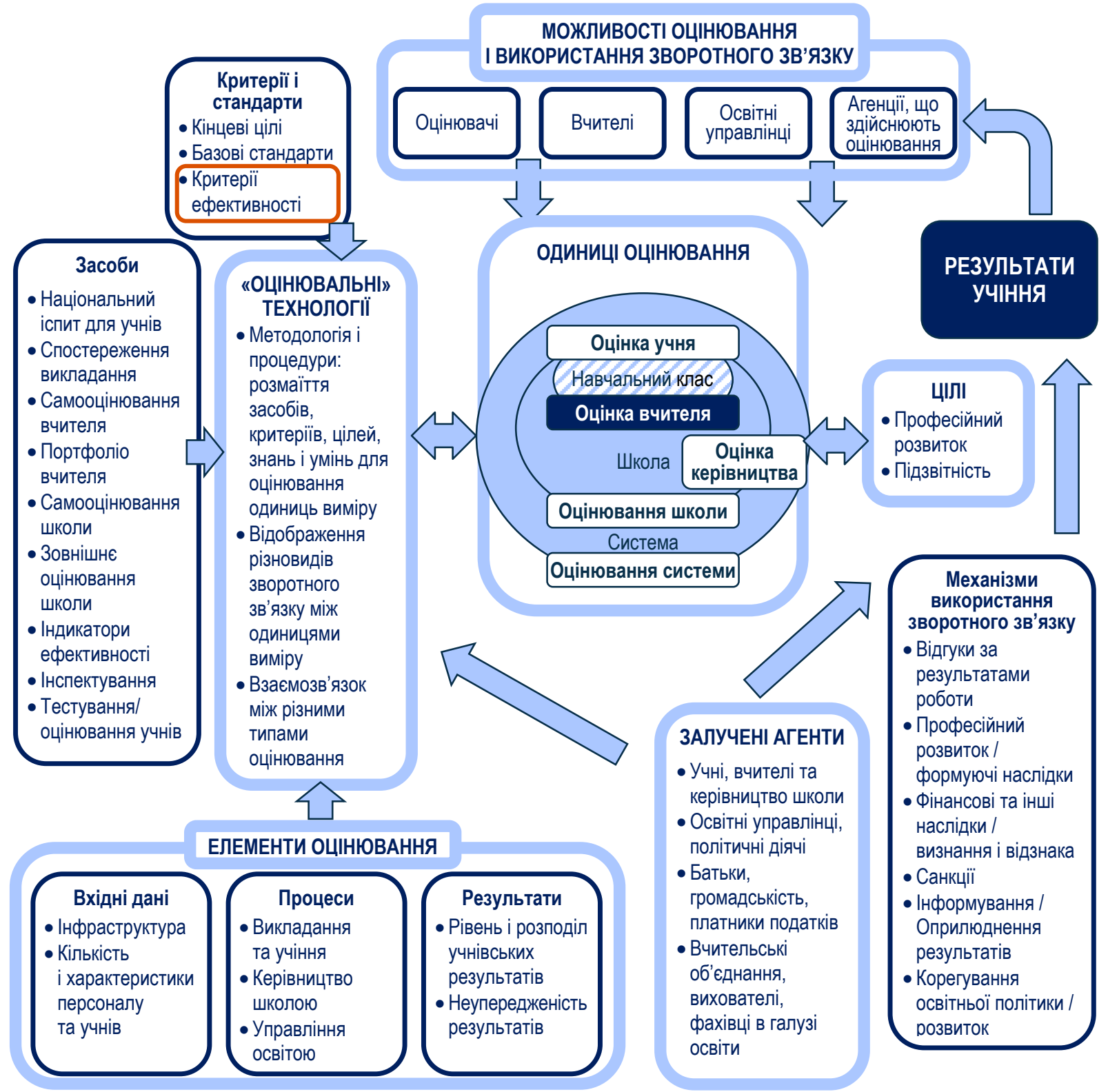

Рис. 1. Рекомендована країнам - членам ОЕСР структура системи оцінки шкільної освіти (P. Santiago, 2013) 
У результаті її вивчення ми дійшли висновку, що концептуальна рамка викладання Ш. Даніелсон належить до оцінювальних технологій, за допомогою яких піддаються оцінці суб'єкти освітньої діяльності. Зазначені ж оцінювальні технології $€$ невід'ємним складником системи оцінки шкільної освіти.

Розглянемо підсистеми рамки. Критеріальний комплекс, репрезентований в актуальній версії (2013) під назвою «Framework for Teaching. Evaluation Instrument», включає:

- набір критеріїв, що характеризують 22 професійні вчительські якості, які, за умови їх розвитку та вдосконалення, потенційно позитивно впливають на учнівські досягнення (що доведено дослідженнями);

- показники критеріїв, що конкретизують їх найважливіші грані;

- індикатори критеріїв, тобто стислі описи спостережуваних проявів критеріїв, необхідні для конструювання шкал критеріїв;

- вербальні порядкові шкали критеріїв, кожна з яких $€$ таблицею, що містить впорядковані за чотирма рівнями продуктивності (незадовільний, базовий, вправний; видатний): описи перевірених дослідженнями оцінювальних суджень щодо градацій інтенсивності індикаторів критерію;

- спеціальні інструменти, покликані допомогти експерту зробити якнайточніші оцінки для кожного критерію: описи критичних атрибутів (приклади недопустимої поведінки вчителя) та описи прикладів належної поведінки вчителя.

Набір критеріїв приблизно рівномірно розподілений за чотирма сферами (доменами) професійної практики вчителя (рис. 2).

ПЛАНУВАННЯ I ПІДГОТОВКА

\section{УМОВИ НАВЧАННЯ}

1а. Демонструє знання предметної галузі і педагогіки

1b. Демонструє знання особливостей учнів

1c. Демонструє знання інформаційних ресурсів

1d. Установлює навчальні результати 1е. Проєктує узгоджені у часі програми

1f. Проєктує засоби оцінювання 2а. Створює атмосферу поваги і взаєморозуміння

2b. Розвиває культуру учіння

2c. Керує процедурами навчання

2d. Керує поведінкою учнів

2е. Облаштовує фізичне середовище класу 4а. Аналізує власні профресійні дії

4b. Точно документує процеси і результати власної праці

4c. Взаємодіє з родинами

4d. Бере участь у професійних об'єднаннях

4е. Розвивається і професійно зростає

4f. Демонструє професіоналізм
За. Спілкується з учнями

3b. Використовує методи опитування та обговорення

3с. Залучає школярів до діяльності учіння

3d. Оцінює навчальні здобутки учнів

Зе. Демонструє гнучкість i відповідальність

\section{ПРОФЕСІЙНІ ЗОБОВ'ЯЗАННЯ}

\section{4}

\section{ВИКЛАДАННЯ}

3

Рис. 2. Упорядкований за доменами набір критеріїв для оцінювання ефективності вчительської праці (○ Ch. Danielson)

Представлені на рис. 2 формулювання критеріїв вочевидь мають універсальний характер для будь-яких вчительських спеціалізацій. Аби застосувати критеріальний комплекс до оцінювання роботи вчителя конкретної спеціалізації, необхідно наповнити відповідним змістом показники, індикатори та оцінювальні шкали певної групи критеріїв, а саме: «Демонструє знання предметної галузі та педагогіки», «Установлює навчальні результати», «Проєктує узгоджені у часі програми» тощо.

За твердженням Ш. Даніелсон, центральним компонентом у розглядуваному наборі критеріїв $\epsilon$ здатність вчителя залучати школярів до діяльності учіння (learning). У коментарі до цього критерію наголошується: ефективний вчитель має заохотити учнів до осмисленого оволодіння навчальним матеріалом шляхом обговорень, дискусій, а також запитаннями на кшталт «А якщо?..». Дієвим прийом залучення школярів до участі в інтелектуальному житті класу також $\epsilon$ надання їм можливості самостійно обирати завдання з набору, запропонованого вчителем.

Сфери професійної практики вчителя, критерії i їх показники утворюють трирівневу ієрархічну структуру, яка $€$ узагальненою моделлю процесуальної сторони вчительської праці. Перший рівень, позначений як домени, - це назви сфер вчительської практики. Другий рівень, позначений як компоненти, - це професійні якості вчителя, асоційовані з критеріями. Третій рівень, позначений як елементи, - це показники критеріїв. Рис. 3 містить схему цієї структури. 


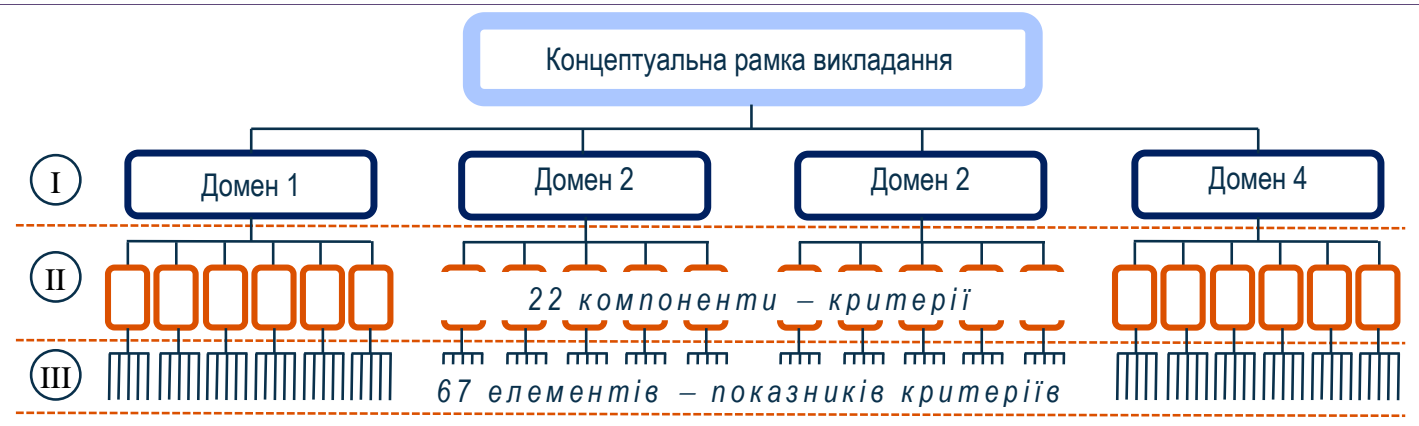

Рис. 3. Схема структури концептуальної рамки викладання Ш. Даніелсон

Впадає в око, що складники ієрархічних рівнів рамки позначено стилістично нейтральними словами: домени, компоненти, елементи. Вважаємо це досить вдалим авторським прийомом. Адже відсутність у вживаних словах побічних смислів сприяє концентрації уваги читачів на змісті їі складників та запобігає привнесенню до його розуміння суб'єктивних деталей.

Розгляд концептуальної рамки викладання з позицій системного підходу доцільно завершити розглядом їі функцій. За твердженням Ш. Даніелсон, її оцінювальний інструмент забезпечує дві функції - оцінювання для професійного розвитку та оцінювання для контролю (Ch. Danielson, 2013).

Щоби збагнути новаторство Ш. Даніелсон, необхідно знати, що передувало виходу в світ першої версії їі рамки. Дж. Мосс зазначає, що 1980-1990-ті роки у США називають ерою контрольованості (era of accountability) вчителів. Це пов'язано з тим, що після оприлюднення звіту «Нація під загрозою: Імператив реформи освіти» (1983) у країні проводилася політика посилення відповідальності вчителів за учнівську успішність, а питання їхнього оцінювання і підзвітності набули національної ваги. Саме у цей період було прийнято рішення долучати до розв'язання проблем у сфері оцінювання вчительської праці приватні компанії (J. Moss, 2015). 3 часом стало очевидно, що надмірний тиск на вчителів спонукає їх залишати професію. Тому виникла потреба у нових моделях оцінювання вчительської праці, які би не тільки відповідали вимогам забезпечення ефективної педагогічної діяльності, а й враховували необхідність професійного розвитку вчителів. Першим прикладом такої моделі у США став інтелектуальний продукт приватної компанії «Danielson Group», оприлюднений у 1996 р. під назвою «Enhancing Professional Practice: A Framework for Teaching» इ «Покращення професійної практики: концептуальна рамка викладання». Видання наступних його версій $(2007,2011,2013)$ містили цінні доповнення, перевірені під час досліджень.

\section{ОБГОВОРЕННЯ}

Для досягнення мети нашого дослідження варто з'ясувати сутність керівних ідей, покладених в основу аналізованого нами критеріального комплексу оцінювання вчительської праці. За твердженням Ш. Даніелсон, концептуальна рамка викладання базується на принципах конструктивізму (Ch. Danielson, 2013).

Педагогічний конструктивізм - це підхід до учіння, який твердить: люди активно конструюють чи створюють свої власні знання, а реальність визначається досвідом учня. Педагогічний конструктивізм істотно переглядає роль вчителя у пізнавальному процесі. Ця роль і далі $\epsilon$ головною, але вона стає «невидимою». Організуючи процес навчання, вчитель керує не думками і діяльністю учнів, а створює сприятливе середовище для активізації цієї миследіяльності (В. Богданова, 2012). Внаслідок розвитку ідей педагогічного конструктивізму на противагу традиційній «парадигмі викладання», тобто підходу, зорієнтованого на викладача, сформувалася «парадигма учіння», тобто підхід, зорієнтований на студента/учня. 3 позицій «парадигми учіння» ефективність викладання оцінюється на основі його впливу на діяльність учіння (R. Barr \& J. Tagg, 1995).

3 урахуванням викладеного вище вважаємо, що до показових прикладів втілення ідей конструктивізму в змісті концептуальної рамки викладання можна віднести:

- асоціювання оцінювальних критеріїв з тими вчительськими професійними якостями, які потенційно позитивно впливають на учнівські досягнення;

- визнання Ш. Даніелсон та їі співавторами переважного значення здатності вчителя залучати школярів до діяльності учіння.

Осмислення цієї вчительської здатності змусило нас звернутися до поняття «Student Engagement» $\equiv$ «Залучення студентів/учнів до діяльності учіння». Цей феномен у науковій літературі тлумачать як сукупність фізичної і психологічної енергії людини, що витрачається нею для набуття академічного досвіду і виражається у її поведінці. (Н. Малошонок, 2014).

На нашу думку, приватна компанія «Danielson Group» займає на ринку освітніх послуг США досить міцні позиції. Адже, за даними Дж. Мосса, шкільні округи майже 30 штатів обрали критеріальний комплекс Даніелсон за основу для розбудови власної системи оцінювання вчительської праці (J. Moss, 2015). Цей факт передбачає оплату за підготовку експертівоцінювачів з числа адміністративних працівників на чолі з директором для кожної школи округу. Іншою значною групою споживачів рамки $\epsilon$ вчителі-початківці, які мають ґрунтовно підготуватися до складних випробувань, пов'язаних 3 отриманням професійної ліцензії. 3 викладеного випливає, що предметом продажу «Danielson Group» $€$ не сама концептуальна рамка викладання, а технології ї̈ застосування у вигляді навчальних курсів. Універсальний характер набору оцінювальних критеріїв уможливлює створення уніфікованих і стандартизованих навчальних програм для цих курсів, що, у свою чергу, сприяє ефективному використанню персоналу компанії «Danielson Group», задіяному у проведенні курсів.

За нашими спостереженнями, розглянутий набір оцінювальних критеріїв підходить під вимоги, що розроблені у теорії прийняття рішень до багатокритеріальних задач. Обґрунтуємо його повноту, дієвість і вимірюваність. 
Набір критеріїв вважається повним, якщо використання будь-яких додаткових критеріїв не змінює результатів розв'язання задачі, а відкидання хоча б одного з вибраних критеріїв призводить до зміни результатів (М. Гафт, 1979).

Перевіримо повноту аналізованого набору критеріїв, відповівши на питання: які вчительські професійні якості, асоційовані з критеріями ефективного вчителя за версією Ш.Даніелсон, входять до моделі процесуальної сторони вчительської праці за версією А. Маркової? Це питання вважаємо доречним, оскільки обидві дослідниці переймалися процесуальною стороною вчительської праці та критеріями оцінювання її ефективності.

Складники моделі процесу вчительської праці за А. Марковою - педагогічна діяльність, педагогічне спілкування та професійна самореалізація особистості вчителя.

У психологічно цілісній педагогічній діяльності дослідниця виокремлює три компоненти:

1) постановка вчителем педагогічних цілей та завдань;

2) вибір та застосування засобів впливу на тих, хто навчається;

3) контроль та оцінювання вчителем своїх власних педагогічних впливів (педагогічний самоаналіз).

Керуючись цим положенням А. Маркової, до складника «педагогічна діяльність» ї̈ моделі ми віднесли такий набір $з$ десять професійних якостей ефективного вчителя за версією Ш. Даніелсон:

1d. Установлює навчальні результати.

1е. Проєктує узгоджені у часі програми.

1f. Проєктує засоби оцінювання.

1а. Демонструє знання предметної галузі і педагогіки.

1b. Демонструє знання особливостей учнів.

1c. Демонструє знання інформаційних ресурсів.

Зс. Залучає учнів до діяльності учіння.

3b. Використовує методи опитування та обговорення.

2е. Облаштовує фізичне середовище класу.

4а. Аналізує власні професійні дії.

Стосовно педагогічного спілкування А. Маркова звертає особливу увагу на його правильну організацію, адже атмосферу спрямованості на розвиток особистості учня створює саме вчитель. У взаємодії «учитель - учень» дослідниця виділяє три групи словесних впливів учителя на учня: організуючий вплив (інструктування, розпорядження, повчання, спонукання тощо); оцінювальні дії (з позитивним знаком - похвала, з негативним знаком - критичні зауваження, оцінки); дисциплінуючий вплив (зауваження-запитання, зауваження-твердження, підвищення голосу тощо). До того ж, вона зазначає, що педагогічним називають не тільки спілкування вчителя з учнями, а й з іншими учасниками навчально-виховного процесу (вчитель - вчитель, вчитель - директор школи, вчитель - батьки тощо). Відтак, до складника «педагогічне спілкування» доречно віднести такі дев'ять професійних якостей за Ш. Даніелсон:

2а. Створює атмосферу поваги і взаєморозуміння.

2b. Розвиває культуру учіння.

За. Спілкується з учнями.

2c. Керує процедурами навчання.

2d. Керує поведінкою учнів.

3d. Оцінює навчальні здобутки учнів.

4c. Взаємодіє з родинами.

Зе. Демонструє гнучкість і відповідальність.

4d. Бере участь у професійних об'єднаннях.

Пріоритетною інтегральною характеристикою вчителя як особистості А. Маркова визначає його професійну педагогічну самосвідомість, тобто комплекс уявлень учителя про себе як професіонала (А. Маркова, 1992). Тому складник «професійна самореалізація особистості вчителя» вміщує, на нашу думку, такі три професійні якості ефективного вчителя за Ш.Даніелсон:

4е. Розвивається і професійно зростає.

4f. Демонструє професіоналізм.

4b. Точно документує процеси і результати власної праці

Очевидно, що, попри різні методологічні позиції Ш. Даніелсон і А. Маркової, їхні погляди на сутність ефективної вчительської праці у цілому збігаються. На нашу думку, цей факт, нехай і опосередковано, свідчить про повноту набору критеріїв ефективності вчительської праці за версією Ш. Даніелсон.

Наступна вимога «дієвість набору критеріїв» означає, що кожен критерій повинен мати зрозуміле для особи, яка приймає рішення, формулювання, ясний і однозначний зміст (М. Гафт, 1979). Наявність цих властивостей у формулюваннях розглядуваних критеріїв не викликає сумніву.

Згідно з вимогою «вимірюваність», кожен критерій має допускати можливість оцінки інтенсивності властивості, яку він характеризує (ступеня досягнення відповідної мети) (М. Гафт, 1979). Властивість «вимірюваність» притаманна розглядуваним критеріям, оскільки кожен з них має оцінювальну шкалу.

За твердженням Ш. Даніелсон, концептуальна рамка викладання покликана забезпечувати дві функції оцінювання вчительської праці - оцінювання для професійного розвитку та оцінювання для контролю. Такий підхід сприяє узгодженню суперечності між органами управління і вчительською спільнотою. Оцінювання вчителів вводиться органами управління в контексті звіту про досягнення і контролю якості, тобто учитель повинен показати і довести ефективність своєї роботи. Вчителі ж противляться такому підходу. Вони хочуть зберегти автономію і хочуть такого оцінювання своєї праці, яке слугуватиме їхньому професійному зростанню, вдосконаленню педагогічної роботи та розвитку школи (В. Загвоздкин, 2018). 


\section{ВИСНОВКИ ТА ПЕРСПЕКТИВИ ПОДАЛЬШОГО ДОСЛІДЖЕННЯ}

За результатами нашої розвідки ми виявили чотири відмітні особливості концептуальної рамки викладання Ш. Даніелсон, які відрізняють її від набору критеріїв оцінювання професійної компетентності вчителів, розроблених Державною службою якості освіти України:

1. Рамка ґрунтується на ідеях педагогічного конструктивізму. Запропоновані у ній оцінювальні критерії характеризують перевірені дослідженнями вчительські якості, котрі достовірно корелюють із досягненнями учнів. Першорядною з них визнано здатність вчителя залучати школярів до учіння.

2. Репрезентовані у рамці критерії оцінювання процесуальної сторони педагогічної праці $є$ універсальними для будь-яких викладацьких/учительських спеціалізацій.

3. Набір цих критеріїв певною мірою задовольняє вимоги, передбачені теорією прийняття рішень для багатокритеріальних задач. Йому властиві повнота, дієвість і вимірюваність.

4. Рамка покликана забезпечувати дві функції оцінювання праці вчителів - оцінювання для професійного розвитку та оцінювання для контролю.

Безумовно, представлений огляд концептуальної рамки викладання Ш. Даніелсон не є вичерпним. Ми зосередили нашу увагу лише на їі ключових аспектах. Складові кожного критерію варті окремого осмислення та усвідомлення.

Перспективу подальших досліджень вбачаємо у вивченні оцінювального інструменту «The Added Value Model» («Модель із доданою вартістю»), призначеного для оцінювання результативної сторони вчительської праці.

\section{Список використаних джерел}

1. Богданова В. Конструктивистские идеи в педагогике: от адаптации к свободе. Педагогический журнал. 2012. № 2-3. C. 23-38 URL: http://www.publishing-vak.ru/file/archive-pedagogy-2012-2/2-bogdanova.pdf (Дата звернення: 28.08.21).

2. Гафт М. Принятие решений при многих критериях. М. : Знание, 1979. 64 c.

3. Загвоздкин В. Проблема оценки качества работы учителя. Народное образование. 2018. № 10. C. 89-98. URL: https://cyberleninka.ru/article/n/problema-otsenki-kachestva-raboty-uchitelya (Дата звернення: 28.08.21).

4. Зварич І. Очінювання професійної діяльності викладачів у вищих навчальних закладах США (друга половина ХX початок XXI століття). Київ : Фенікс, 2014. 344 с.

5. Макаров И., Виноградская Т., Рубчинский А., Соколов В. Теория выбора и принятия решений. М. : Наука, 1982. 328 с.

6. Малошонок Н. «Студенческая вовлеченность» как социальное явление: теория и методология исследования: автореф. дис. ... к-та социол. наук: 22.00.01 / ВШэ. Москва, 2014. 36 c. URL: https://www.hse.ru/sci/diss/124050733 (Дата звернення: 28.08.21).

7. Маркова А. Психология труда учителя. М. : Просвещение, 1993. 192 с.

8. Мучински Дж. Психология, профессия, карьера. СПб. : Питер, 2004. 539 с.

9. Строкова Т. О выборе критериев оценки в педагогических исследованиях. Педагогика, 2015. № 3. С. 9-15.

10. Barr R., Tagg J. From Teaching to Learning: A New Paradigm for Undergraduate Education. Change, 1995. № 6. P. 13- 26. DOI: https://doi.org/10.1080/00091383.1995.10544672.

11. Cantrell, St. The Measures of Effective Teaching Project: An Experiment to Build Evidence and Trust. Education Finance and Policy, 2012. № 7(2). P. 1-16. DOI: https://doi.org/10.1162/EDFP_a_00062.

12. Danielson Ch. Framework for Teaching. Evaluation Instrument. $2013 . \quad$ URL: https://danielsongroup.org/products/product/framework-teaching-evaluation-instrument (Last accessed 28.08.21).

13. Moss, J. The Danielson Model of Teacher Evaluation: Exploring Teacher Perceptions Concerning Its Value in Shaping and Improving Instructional Practice: doctoral dissertation of Political Science / Seton Hall University. New Jersey, 2015. 243 p. URL: https://scholarship.shu.edu/cgi/viewcontent.cgi?article=3133\&context=dissertations (Last accessed 28.08.21).

14. Santiago, P. The evaluation and assessment framework. OECD Reviews of Evaluation and Assessment in Education "Synergies for Better Learning. An International Perspective on Evaluation and Assessment". OECD, 2013. Chapter 3. P. 57-138. DOI: https://doi.org/10.1787/9789264190658-en.

\section{References}

1. Bohdanova, V. (2012). Konstruktivistskie idei v pedagogike: ot adaptacii k svobode. Pedagogicheskij zhurnal, 2-3, 23-38. URL: http://www.publishing-vak.ru/file/archive-pedagogy-2012-2/2-bogdanova.pdf [in Russian].

2. Haft, M. (1979). Prinjatie reshenij pri mnogih kriterijah [Decision-making under many criteria]. Znanie [in Russian].

3. Zahvozdkyn, V. (2018). Problema ocenki kachestva raboty uchitelja. Narodnoe obrazovanie, 10, 89-98. URL: https://cyberleninka.ru/article/n/problema-otsenki-kachestva-raboty-uchitelya [in Russian].

4. Zvarich, I. (2014). Otsiniuvannia profesiinoi diialnosti vykladachiv u vyshchykh navchalnykh zakladakh SShA (druha polovyna KhKh - pochatok KhKhl stolittia). Feniks [in Ukrainian].

5. Makarov, Y., Vinogradskaja, T., Rubchinskij A., \& Sokolov V. (1982). Teorija vybora i prinjatija reshenij [Theory of choice and decision-making]. Nauka [in Russian].

6. Maloshonok, N. (2014). Studencheskaja vovlechennost'» kak social'noe javlenie: teorija i metodologija issledovanija ["Student Engagement" as a social phenomenon: theory and methodology of research]. [Doctoral dissertation, HSE University] HSE University. Retrieved from: https://www.hse.ru/sci/diss/124050733 [in Russian].

7. Markova, A. (1993). Psihologija truda uchitelja [Psychology of teacher work]. Prosveshhenie [in Russian]

8. Muchinsky, P. (2004). Psihologija, professija, kar'era [Psychology, profession, career]. Piter [in Russian].

9. Strokova, T. (2015). O vybore kriteriev ocenki v pedagogicheskih issledovanijah [On the choice of evaluation criteria in pedagogical research]. Pedagogika, 3, 9-15. [in Russian].

10. Barr R., \& Tagg J. (1995). From Teaching to Learning: A New Paradigm for Undergraduate Education. Change, 6, 13- 26. DOI: https://doi.org/10.1080/00091383.1995.10544672 [in English]. 
11. Cantrell, St. (2012). The Measures of Effective Teaching Project: An Experiment to Build Evidence and Trust. Education Finance and Policy, 7(2), 1-16. DOI: https://doi.org/10.1162/EDFP_a_00062 [in English].

12. Danielson Ch. (2013). Framework for Teaching. Evaluation Instrument. Retrieved from: https://danielsongroup.org/products/product/framework-teaching-evaluation-instrument [in English].

13. Moss, J. (2015). The Danielson Model of Teacher Evaluation: Exploring Teacher Perceptions Concerning Its Value in Shaping and Improving Instructional Practice. [Doctoral dissertation, Seton Hall University]. Seton Hall University Dissertations and Theses. https://scholarship.shu.edu/cgi/viewcontent.cgi?article=3133\&context=dissertations [in English].

14. Nusche D., Radinger Th., Santiago P., \& Shewbridge Cl. (2013). The evaluation and assessment framework. In P. Santiago (Ed), OECD Reviews of Evaluation and Assessment in Education "Synergies for Better Learning. An International Perspective on Evaluation and Assessment" (pp. 57-138). OECD. DOI: https://doi.org/10.1787/9789264190658-en [in English].

\section{SPECIFICITY OF THE EVALUATING INSTRUMENT OF DANIELSON FRAMEWORK FOR TEACHING}

(The U.S. Experience)

Taiana Dieorditsa

Charitable foundation "e-Terra", Ukraine

Maryna Voronina

Kyiv National University of Culture and Arts, Ukraine

Nataliia Litvinova

Abstract.

Oleksandr Dovzhenko Hlukhiv National Pedagogical University, Ukraine

Formulation of problem. According to our observations, the sets of criteria for evaluating teaching, developed in 2019-2020 by specialists of the State service of education quality, do not have the property of measurability. But the measurable criteria make it possible to identify levels of professionalism. Scales of criteria serve to do this. If there are no evaluation scales, the procedure for expert evaluation is replaced by the procedure for monitoring compliance with the requirements. And this discredits the idea of evaluation for professional development. Thus, reviews of the best foreign technologies for evaluating effective teaching are relevant. Our study was guided by the following research question: what are the distinctive features inherent in the criteria used in the U.S. to evaluate the teaching work?

Materials and Methods. We made a review of popular in the U.S. the evaluating instrument "Framework for Teaching" by Ch. Danielson to find out its distinctive features. We did it from the standpoint of a systems approach.

Results. Danielson's Framework for Teaching represents the criterion complex necessary for expert evaluation of the teaching work's effectiveness. A set of 22 criteria is the core of it. Criteria characterize professional teacher qualities that affect student performance. Each criterion has characteristics, indicators, and scale. Characteristics specify the most important facets of the criterion. Indicators are used to construct a scale of a criterion. The scale includes descriptions of evaluative judgments.

Conclusions. Based on the results of our study, we established four distinctive features of the criteria under consideration. First, their theoretical basis is the ideas of pedagogical constructivism. Secondly, the criteria are universal for all teaching specializations. Third, the set of criteria is complete, actionable and measurable. Fourth, the criterion complex provides two evaluation functions: development and accountability.

Key words: teaching work, evaluating instrument, set of criteria, criterion complex, expert evaluation, pedagogical constructivism, student engagement. 